\title{
PENGARUH EVENT PARIWISATA DAN PHYSICAL EVIDENCE TERHADAP KEPUTUSAN BERKUNJUNG
}

\author{
Fahmiroellah Fariz Ismail \\ Universitas Negeri Surabaya \\ fahmiroellahismail@mhs.unesa.ac.id \\ Sri Setyo Iriani \\ Universitas Negeri Surabaya \\ srisetyo@unesa.ac.id
}

\begin{abstract}
Indonesia is a maritime country, and it has more than thousands of beautiful islands. Those are the main reasons many domestic or even international tourists choose Indonesia for a holiday. White Sand Beach in Situbondo is one of the most visited tourist attractions. The local government that manages this place uses tourism events as a promotional medium and improves the physical evidence to attract more tourists to White Sand Beach for holidays. Therefore, this study aims to determine how effective tourism events and physical evidence influence the decision to visit this place. The survey was conducted using an online questionnaire and collected data from 50 early adult respondents who had visited the Beach. The data obtained were analyzed quantitatively through multiple linear regression analysis techniques in SPSS. This study shows that tourism events and physical evidence have a significant effect on visiting decisions. For further research, this study recommends comparing several different tourist attractions by adding variables and expanding the scope of respondents. The local government that manages the White Sand Beach tourism can use the findings as evaluation materials.
\end{abstract}

Keywords: event tourism; physical evidence; purchase decision.

\section{PENDAHULUAN}

Letak Indonesia secara geografis berada di tengah benua Asia dan benua Australia serta samudera Hindia dan samudera Pasifik. Indonesia merupakan sebuah negara maritime, gabungan dari beberapa pulau sehingga memiliki wisata pantai dengan kecantikan dan memiliki sumber daya hayati yang tinggi. Tergabungnya dari banyaknya pulau, juga menghasilkan negara yang memiliki keindahan pantai yang sangat diminati oleh wisatawan lokal maupun asing. Letak yang sangat strategis dimanfaatkan pemerintah pusat maupun daerah untuk memerhatikan dan mengembangkan pariwisata. (Sahabatnesia.com, 2018)

Pemerintah daerah Kabupaten Situbondo telah lama mengelola Wisata Pantai Pasir Putih. Wisata tersebut berada tepat di pinggir jalan pantura jalur Surabaya menuju Banyuwangi ataupun Bali. Letak yang strategis banyak orang yang mengetahui keberadaan Wisata Pantai Pasir Putih. Pengembangan yang dilakukan oleh perusahaan daerah mengenai physical evidence atau bukti fisik serta berbagai promosi dilakukan di tempat wisata Pantai Pasir Putih yang telah dikelola sejak tahun 2016 atau tiga tahun yang lalu dikarenakan untuk tahun 2019 Kabupaten Situbondo mencanangkan sebagai tahun kunjungan wisata. (CNN Indonesia, 2018)

Menurut Olson (2013) keputusan konsumen adalah digunakannya proses integrasi untuk memilih dua alternatif atau bisa lebih dari dua alternatif sehingga dapat memilih satu dari sekian pilihan yang menurut konsumen sangat pas untuk dipilih di mana hasil tersebut merupakan suatu kombinasi dari pengetahuan atas beberapa pilihan tersebut. Terdapat tiga faktor dalam menguatkan hingga mendapatkan keputusan konsumen yang pertama adalah strategi pemasaran, kemudian dapat juga dipengaruhi dengan perbedaan individu dan yang terakhir adalah faktor lingkungan. Strategi pemasaran atau marketing mix merupakan salah satu yang berpengaruh terhadap keputusan konsumen Sumarwan (2015). Di dalam strategi pemasaran, terdapat tujuh elemen bauran pemasaran di antaranya adalah product, price, place, promotion, prosess, phyical evidence, dan people (Lovelock et al., 2011). 
Menurut Lovelock et al. (2011), promosi adalah suatu strategi perusahaan untuk membujuk serta memerkenalkan suatu barang maupun jasa yang ditawarkan perusahaan melalui bauran komunikasi pemasaran atau marketing communication mix, dalam bauran komunikasi pemasaran terdapat public relation yang terdiri dari beberapa unsur yaitu event pariwisata, press release kit, press conference, sponsorship, trade show exhibition, dan media rolated coverage.

Event pariwisata mencipatkan citra yang baik sehingga mendapatkan keuntungan bagi suatu destinasi wisata, meningkatkan perkembangan lebih merata, dan berfungsi menarik wisatawan mancanegara maupun wisatawan nusantara(Higgins, 2018). Menurut Getz (2008) event pariwisata memiliki dampak signifikan terhadap keputusan berkunjung serta menambah popularitas kota. Hal ini diperkuat oleh Pakarti et al. (2017) bahwa event pariwisata memiliki pengaruh terhadap variabel keputusan berkunjung.

Pemerintah daerah Kabupaten Situbondo merencanakan tahun 2019 akan dijadikan sebagai tahun kunjungan wisata. Sehingga pemerintah melakukan pengenalan terhadap pariwisata yang terdapat di Kabupaten Situbondo. Promosi yang dilakukan oleh pemerintah daerah dengan memilih event pariwisata sebagai medianya, mulai dari festival musik, event olah raga, serta event kebudayaan. Event tersebut tidak hanya dilakukan oleh pemerintah saja namun komunitas juga ikut serta dalam mempromosikan wisata dan konsisten setiap tahunnya (CNN Indonesia, 2018)

Selain unsur event pariwisata, unsur lain yang berpengaruh dalam keputusan berkunjung adalah unsur physical evidence, di mana variabel physical evidence dapat menyampaikan pesan serta rasa yang perusahaan miliki kepada konsumen serta setiap komponennya yang tangible memfalitasi penampilan perusahaan sehingga terjadi komunikasi jasa (Yazid, 2008). Pernyataan di atas tentang physical evidence berpengaruh terhadap keputusan berkunjung, diperkuat oleh Sabrilia et al. (2016) yang memiliki hasil berupa variabel physical evidence memiliki pengaruh posotif terhadap keputusan berkunjung.

Menurut Pakarti et al. (2017), event pariwisata berdampak positif terhadap keputusan berkunjung. Kemudian Çelik \& Çetinkaya (2013) mendapatkan hasil yang sama berupa event pariwisata berdampak positif terhadap keputusan berkunjung. Hasil yang sama juga diperoleh(Kahuno, 2017), dan Daniel et al. (2018), bahwa event pariwisata berdampak positif yang signifikan terhadap pengambilan keputusan berkunjung.

Selain event pariwisata, physical evidence juga berpengaruh terhadap keputusan berkunjung. Menurut Sabrilia et al. (2016) physical evidence berdampak positif terhadap keputusan berkunjung. Hasil tersebut diperkuat oleh Ananda et al. (2016); Sarsi \& Betty (2017); dan Erisha \& Razati (2017) memiliki hasil berupa physical evidence berdampak positif yang signifikan pada keputusan berkunjung.

Berdasarkan hasil wawancara dengan pengelola wisata pantai Pasir Putih Kab. Situbondo, kelengkapan bukti fisik/ physical evidence serta gencarnya event pariwisata yang dilakukan oleh pemerintah tidak menghasilkan peningkatan jumlah pengunjung. Pada 2018 terjadi penurunan pengunjung yang sangat drastis menjadi 135.933 pengunjung dari tahun 2017 sebanyak 378.100 pengunjung. Pernyataan di atas tidak sesuai dengan Kahuno (2017) pada event pariwisata terhadap keputusan berkunjung dan Getz (2008) pada physical evidence terhadap keputusan berkunjung, di mana ketika intensitas event dilakukan sangat tinggi dan pengembangan bukti fisik dibenahi, terjadi peningkatan keputusan berkunjung yang berujung pada tingkat volume wisatawan.

Berdasarkan research gap dan fenomena di atas, tujuan penelitian ini untuk menganalisis, apakah terdapat pengaruh event pariwisata dan physical evidence terhadap keputusan berkunjung pada obyek wisata Pantai Pasir Putih Kabupaten Situbondo.

\section{KAJIAN PUSTAKA DAN PENGEMBANGAN HIPOTESIS}


Fahmiroellah Fariz Ismail \& Sri Setyo Iriani. Pengaruh Event Pariwisata dan Physical evidence terhadap Keputusan Berkunjung

\section{Event Pariwisata}

Event pariwisata menurut Getz (2008) adalah sesuatu kegiatan yang dikelola dengan professional dan telah banyak dilakukan di mana wisatawan menjadi target konsumen potensial untuk kegiatan yang akan diselenggarakan dan industri pariwisata berpengaruh dalam kesuksesan dan daya tarik kegiatan itu sendiri. Menurut Any (2009), event adalah suatu agenda yang dibuat untuk memeringati hal-hal penting di masyarakat baik secara individu atau kelompok yang terikat secara nilai adat, nilai budaya, nilai tradisi dan agama yang dibuat untuk tujuan tertentu serta melibatkan lingkungan masyarakat yang diselenggarakan pada waktu tertentu. Faktor-faktor yang dapat menambah kulalitas event. Menurut Getz (2008), terdapat delapan aspek yaitu festive spirit, uniqueness, authenticity, tradition, quality, hospitality, theming, symbolism. Indikator variabel event pariwisata pada penelitian ini mengacu pada Getz (2008) .

\section{Physical Evidence}

Aspek yang dapat membantu perusahaan di bidang jasa agar lebih terlihat menarik dan menaikan rasa percaya konsumen terhadap produknya dilihat dari situasi, kondisi tempat, dan lingkungan perusahaan merupakan bukti fisik atau physical evidence (Henry, 1992). Physical evidence adalah tersedianya fasilitas perusahaan, kelengkapan ruangan, dan sarana komunikasi dalam proses jasa (Sabrilia et al., 2016). Indikator yang digunakan dalam variabel physical evidence adalah facility exterior, facility interior, dan other tangible (Erisha \& Razati, 2017).

\section{Keputusan Berkunjung}

Menurut Pakarti et al. (2017) keputusan berkunjung merupakan tahapan akhir dari serangkaian proses yang terjadi pada perilaku konsumen. Menurut Hartiningsih \& Rokhmah (2017), definisi keputusan pembelian adalah tahapan keputusan di mana konsumen secara actual dengan mencari informasi sebelum melakukan pembelian suatu produk. Keputusan berkunjung wisatawan diadaptasi dari konsep keputusan pembelian konsumen. Indikator keputusan berkunjung diadopi dari Daniel et al. (2018) yaitu pengenalan masalah; pencarian informasi; evaluasi; membuat alternatif untuk berlibur; keputusan berkunjung; dan perilaku pasca pembelian.

\section{Hubungan antar Variabel}

Menurut Getz (2008), event pariwisata memiliki dampak yang positif dari keputusan berkunjung sehingga memiliki fungsi meningkatkan kunjungan wisatawan untuk datang dan berlibur ke kota tersebut. Event pariwisata berdampak signifikan terhadap keputusan berkunjung dengan menyumbang hasil sebesar 0,507 atau 50,7\% (Pakarti et al., 2017). Hasil yang sama dikemukakan oleh (Kahuno, 2017)dan Fitriani \& Andari (2016) bahwa event pariwisata berpengeruh terhadap keputusan berkunjung.

H1: Terdapat pengaruh positif antara event pariwisata terhadap keputusan berkunjung.

Hubungan antara variabel physical evidence terhadap keputusan berkunjung dijelaskan oleh Ratih (2008) bahwa physical evidence adalah suatu aspek yang terdapat di lingkungan perusahaan, letak geografis, dan media komunikasi antara perusahaan dan konsumen sehingga mampu memengaruhi konsumen untuk menggunakan jasa yang ditawarkan. Menurut Hartiningsih \& Rokhmah (2017) terdapat pengaruh antara physical evidence terhadap keputusan konsumen.

H2: Terdapat pengaruh positif antara physical evidence terhadap keputusan berkunjung.

\section{METODE PENELITIAN}

Penelitian ini menggunakan metode konklusif. Metode tersebut bertujuan menguji hipotesis dan hubungan antara data yang diperoleh serta dilakukan analisis kuantitatif (Malhotra, 2009). Data yang digunakan adalah data primer yang diperoleh melalui penyebaran kuisioner kepada 50 responden yang telah melakukan kunjungan dengan menggunakan google form. Instrumen penelitian terdiri dari 16 
pertanyaan untuk variabel event pariwisata, 6 pertanyaan untuk variabel physical evidence, dan 8 pernyataan untuk variabel keputusan berkunjung. Skala yang digunakan dalam kusioner adalah skala likert. Skala ini digunakan sebagai tolak ukur antara sangat setuju dan sangat tidak setuju terhadap suatu pernyataan. Responden yang dipilih adalah pria dan wanita yang pernah mengunjungi atau menginap di wisata pantai Pasir Putih Kab. Situbondo, berusia pada 19 tahun ke atas. Teknik sampling menggunakan non-probability sampling dan menggunakan pengambilan data snowball sampling. Pengambilan data snowball sampling dilakukan dengan membagikan angket kepada salah satu responden selajutnya responden tersebut merekomendasikan ke responden lainnya hingga jumlah sampel terpenuhi. Teknik analisis data menggunakan regresi linier berganda dengan software IBM Statistic SPSS versi 26. Analisis data meliputi uji validitas, uji reliabilitas, uji asumsi klasik dan pengujian hipotesis yaitu uji $\mathrm{F}$ dan uji $\mathrm{t}$.

\section{HASIL DAN PEMBAHASAN}

\section{Karakteristik Responden}

Jumlah keseluruhan responden terdiri dari 50 responden, sebanyak $31(61,4 \%)$ adalah pria dan 19 $(38,6 \%)$ adalah wanita. Wisatawan dengan usia 19-21 tahun adalah sebanyak 13 (26,3\%) orang, usia 22-24 tahun berjumlah $20(38,6 \%)$ orang, dan wisatawan di atas 24 tahun berjumlah $17(35,1 \%)$ orang. Pekerjaan setiap wisatawan berbeda-beda, untuk mahasiswa 17 orang $(33,3 \%)$, kemudian PNS sebanyak 4 orang $(8,8 \%)$, wiraswasta sebanyak 8 orang $(15,8 \%)$, di bidang swasta 9 orang $(19,3 \%)$, dan lainnya sebanyak 12 orang $(22,8 \%)$. Persentase frekuensi kunjungan untuk wisatawan satu kali kunjungan sebanyak 5 orang $(10,5 \%)$ dan untuk yang berkunjung lebih dari satu kali sebanyak 45 orang $(89,5 \%)$.

\section{Uji Validitas}

Suatu pertanyaan dinyatakan valid apabila nilai r-hitung atau correlated items-total correlation lebih besar dari r-tabel (Ghozali, 2013). Hasil analisis data, semua indikator mendapatkan nilai r-hitung yang lebih besar dari r-tabel yaitu 0.2787 , maka semua indikator valid. Variabel X1 event pariwisata memiliki nilai 0.603 dan variabel X2 physical evidence memiliki nilai 0.784 . Sedangkan pada variabel Y yaitu keputusan berkunjung memiliki nilai 0.691 , sehingga semua pertanyaan dalam indikator dinyatakan valid.

\section{Uji Reliabilitas}

Variabel dikatakan reliabel jika nilai cronbach's alpha> 0.70 (Ghozali, 2011). Dilihat dari hasil croncbach's alpha pada setiap variabel memiliki nilai lebih besar dari 0.70, variabel event pariwisata sebesar 0.905, physical evidence memiliki hasil 0.820, dan variabel keputusan berkunjung memiliki nilai cronbach's alpha sebesar 0.888. Maka semua variabel dinyatakan reliabel.

\section{Uji Normalitas}

Hasil perhitungan uji normalitas menggunakan one sample kolmogorov smirnov diketahui bahwasanya nilai sig. (2-tailed) adalah 0.200 , sehingga data terdistribusi normal.

\section{Uji Multikolinieritas}

Multikolinieritas pada setiap persamaan dapat dilihat dari nilai VIF dan nilai tolerance yang dihasilkan. Data terbebas dari multikolinieritas apabila nilai VIF kurang dari 10 dan nilai tolerance harus lebih dari 0.01 . Hasil pengujian diperoleh nilai tolerance 0.633 lebih besar dari 0.01 dan VIF 1.579 lebih kecil dari 10 pada kedua variabel independen secara berurutan. Maka dapat dinyatakan tidak terjadi multikolinieritas.

\section{Uji Heterokedastisitas}

Uji glejser dilakukan untuk menguji heterokedastisitas dengan konsekuensi nilai signifikansi harus lebih besar dari 0.05 agar tidak terjadi heterokedastisitas dan sebaliknya. Diketahui dari hasil uji glejser bahwa kedua variabel independen pada persamaan pertama menghasilkan nilai signifikansi yang lebih 
Fahmiroellah Fariz Ismail \& Sri Setyo Iriani. Pengaruh Event Pariwisata dan Physical evidence terhadap Keputusan Berkunjung

besar dari 0.05 di antaranya variabel event pariwisata memiliki hasil sebesar 0.071 dan physical evidence memiliki hasil sebesar 0.143. Maka tidak terjadi heterokedastisitas.

Setelah diperoleh hasil uji asumsi klasik dan semua asumsi telah terpenuhi, selanjutnya adalah hasil analisis regresi linier berganda. Hasil analisis regresi linier berganda pada tabel 1.

Tabel 1.

HASIL ANALISI REGRESI LINIER BERGANDA

\begin{tabular}{llccc}
\hline Model & & $\begin{array}{c}\text { Unstandardized Coefficients } \\
\boldsymbol{B}\end{array}$ & T & Sig. \\
\hline 1 & (Constant) & 1.738 & .448 & .656 \\
& Event Pariwisata & .268 & 4.014 & .000 \\
& Physical evidence & .509 & 2.968 & .005 \\
\hline
\end{tabular}

Sumber : Output SPSS (2021, data diolah)

Berdasarkan tabel 1 diperoleh hasil persamaan model regresi pada persamaan (1).

$\mathrm{Y}=0.268 X 1+0.509 X 2+e$.

Dengan keterangan sebagai berikut :

$\mathrm{Y} \quad=$ Nilai estimasi variabel keputusan berkunjung

$\mathrm{X} 1=$ Nilai variabel event pariwisata

$\mathrm{X} 2=$ Nilai variabel physical evidence

Nilai koefisien pada variabel event pariwisata adalah 0.268 , maka dijelaskan setiap event pariwisata mengalami kenaikan satu satuan, maka event pariwisata akan mengalami peningkatan sebesar 0.268. Nilai positif menunjukkan jika event Pariwisata dan keputusan berkunjung berhubungan yang searah, semakin tinggi event pariwisata yang dirasakan oleh wisatawan maka akan semakin tinggi keputusan berkunjung di wisata Pantai Pasir Putih Kabupaten Situbondo.

Nilai koefisien physical evidence adalah 0.509. Setiap physical evidence mengalami kenaikan satu satuan, maka keputusan berkunjung akan mengalami kenaikan juga sebesar 0.509. Tanda positif menunjukkan jika physical evidence dan keputusan berkunjung memiliki hubungan yang searah, mempunyai arti apabila physical evidence yang dirasakan masyarakat meningkat maka keputusan berkunjung terhadap Pantai Pasir Putih Situbondo juga akan meningkat.

Uji Kelayakan Model

Dalam analisis regresi linier berganda menghasilkan nilai koefision determinasi pada tabel 2.

Tabel 2.

KOEFISION DETERMINASI

\begin{tabular}{llcr}
\hline Model & $\mathbf{R}$ & $\mathbf{R}^{\mathbf{2}}$ & Adjusted $\boldsymbol{R}^{\mathbf{2}}$ \\
\hline & $0.268^{\mathrm{a}}$ & 0.072 & 0.032 \\
\hline Sumber : Output SPSS & $(2021$ data diolah)
\end{tabular}

Tabel 2, kontribusi variabel independen terhadap variabel dependen memiliki nilai adjusted $R^{2}$ sebesar 0.032. Artinya, secara bersama-sama variabel event pariwisata dan physical evidence berpengaruh pada keputusan berkunjung sebesar 3,2\% sedangkan sisanya dipengaruhi oleh variabel lain.

\section{Hasil Uji Hipotesis}

Dasar pengambilan keputusan dari hasil uji t (parsial) adalah :

Jika nilai $\mathrm{t}_{\text {hitung }}<\mathrm{t}_{\text {tabel }}$ atau jika nilai Sig. $>0.05$, maka tidak terdapat pengaruh variabel $\mathrm{X}$ terhadap $\mathrm{Y}$.

Jika nilai $t_{\text {hitung }}>t_{\text {tabel }}$ atau jika nilai Sig. $<0.05$, maka terdapat pengaruh variabel $\mathrm{X}$ terhadap $\mathrm{Y}$. 
Perhitungan nilai $t_{\text {tabel }}$ pada rumus (2).

Rumus $\mathrm{t}_{\text {tabel }}=((\mathrm{a}: 2): \mathrm{n}-\mathrm{k}-1)$

$$
\begin{aligned}
& =((0,05: 2): 50-2-1) \\
& =(0.025: 47) \\
& =2.011
\end{aligned}
$$

Distribusi nilai tabel adalah 2.011

\begin{tabular}{|c|c|c|c|c|c|}
\hline \multirow[b]{2}{*}{ Model } & \multicolumn{2}{|c|}{ Unstandardized Coefficients } & \multirow{2}{*}{$\begin{array}{c}\begin{array}{c}\text { Standardized } \\
\text { Coefficients }\end{array} \\
\text { Beta } \\
\end{array}$} & \multirow[b]{2}{*}{$\mathbf{T}$} & \multirow[b]{2}{*}{ Sig. } \\
\hline & B & Std. Error & & & \\
\hline $1 \quad$ (Constant $)$ & 1.738 & 3.883 & & .448 & .656 \\
\hline Event Pariwisata & 268 & .067 & 483 & 4.014 & .000 \\
\hline Physical Evidence & .509 & .171 & 357 & 2.968 & .005 \\
\hline
\end{tabular}

Tabel 3.

HASIL UJI-T PARSIAL

Sumber : Output SPSS (2021, data diolah).

Berdasarkan tabel 3 diperoleh output coefficients nilai $t_{\text {hitung }}>t_{\text {tabel }}$ yaitu $4.014>2.011$ dan nilai signifikansi (Sig.) X1 terhadap Y sebesar $0.000<0.05$. Maka dapat diartikan H0 ditolak dan H1 diterima, sehingga dapat dikatakan variabel event pariwisata (X1) berpengaruh secara nyata terhadap keputusan berkunjung (Y).

Berdasarkan output coefficients nilai $t_{\text {hitung }}>t_{\text {tabel }}$ yaitu $2.968>2.011$ dan nilai signifikansi (Sig.) $\mathrm{X} 2$ terhadap Y sebesar 0.05. Maka dapat diartikan H0 ditolak dan H2 diterima, sehingga dapat dikatakan variabel physical evidence (X2) berpengaruh secara nyata terhadap variabel keputusan berkunjung (Y).

\section{Pengaruh Event Pariwisata terhadap Keputusan Berkunjung}

Hasil pengujian yang dilakukan, event pariwisata memiliki pengaruh terhadap keputusan berkunjung pada objek wisata Pantai Pasir Putih Kabupaten Situbondo. Hasil di atas mendukung Higgins (2018) yang memiliki hasil yang serupa bahwa event pariwisata berpengaruh positif. Getz (2008) mengatakan bahwa event pariwisata memiliki dampak positif terhadap keputusan berkunjung serta menambah nilai keunggulan kota. Hasil ini juga mendukung Pakarti et al. (2017) bahwa event pariwisata memiliki pengaruh signifikan terhadap variabel keputusan berkunjung. Begitu juga dengan hasil dari Kahuno (2017) bahwa event pariwisata berpengaruh besar terhadap keputusan berkunjung.

Berkaitan dengan aspek yang memengaruhi keputusan berkunjung, event pariwisata memiliki dampak yang baik untuk mengenalkan serta mendapatkan wisatawan baru untuk datang menikmati wisata yang dijadikan tempat sebagai event tersebut. Event yang diselengarakan di wisata Pantai Pasir Putih Kabupaten Situbondo menerapkan beberapa indikator dari delapan indikator sebagai tolak ukur variabel event pariwisata. Event yang menarik karena hanya terdapat di wisata Pantai Pasir Putih dengan menerapkan indikator berupa uniqueness adalah event kepak ayam sap-sap. Event ini merupakan kompetisi terbang ayam yang dilakukan dari tengah pantai hingga ke bibir pantai. Adapun event yang mengadopsi indikator event pariwisata berupa festive spirit yang berupa perayaan malam tahun baru di wisata Pantai Pasir Putih dengan menampilkan musisi Situbondo untuk menghibur pengunjung dengan bermusik. Program event pariwsata bertujuan untuk menjalin kedekatan secara langsung terhadap pengunjung, dari beberapa event yang diselenggarakan hendaknya perusahaan daerah lebih mengkonsep dan merencanakan serta mengadaptasi semua indikator yang terdapat pada variabel event pariwisata. Pemerintah daerah pengelola wisata Pantai Pasir Putih lebih bisa menambah lagi event yang banyak digemari oleh masyarakat Indonesia pada umumnya. Pagelaran festival musik dapat menjadi pilihan yang tepat dengan genre reggae yang menjadi ciri khas musik pantai. Pagelaran festival musik dengan genre reggae dapat diagendakan setiap tahun hingga menjadi event rutin yang diselenggarakan pada musim libur pergantian semester. Filosofi yang dapat diangkat adalah menjadikan wisata Pantai 
Fahmiroellah Fariz Ismail \& Sri Setyo Iriani. Pengaruh Event Pariwisata dan Physical evidence terhadap Keputusan Berkunjung

Pasir Putih yang sangat pas dengan alunan musik reggae sebagai tempat berkumpul para pecinta musik yang beraliran reggae.

Bali dan Yogya memang memiliki wisata budaya maupun wisata alam yang bagus, namun selain faktor tersebut Bali dan Yogya sering ditempati event berskala nasional. Contoh event yang ada di Jogja adalah pameran seni yang dilakukan konsisten setiap tahun dan berskala internasional yang bernama ArtJog, untuk event musik Yogya mengagendakan setiap tahun menampilkan musisi lokal dan internasional bernama Ngayogjazz (Visitingjogja.com, 2016). Sedangkan Bali mengagendakan setiap tahunnya event musik bernama Soundrenaline yang bertempat di Garuda Wisnu Kencana Bali (Soundrenaline.id, 2019)

\section{Pengaruh Physical Evidence terhadap Keputusan Berkunjung}

Variabel physical evidence berpengaruh positif terhadap variabel keputusan berkunjung pada wisata bahari Pantai Pasir Putih Kabupaten Situbondo. Hasil ini mendukung Sabrilia et al. (2016) yang memiliki hasil sama berupa physical evidence berdampak positif terhadap keputusan berkunjung. Kemudian lebih diperkuat lagi oleh hasil dari Ananda et al. (2016). Physical evidence bisa menjadi ujung tombak dalam produk yang bergerak dibidang jasa. Karena wisata merupakan sektor usaha yang termasuk dibidang jasa, hal tersebut harus menjadi sebuah pertimbangan yang sangat besar untuk melengkapi wisata tersebut dengan tiga indikator dari physical evidence. Wisata Pantai Pasir Putih telah menerapkan aspek indikator facility exterior atau fasilitas eksterior yang berupa lahan parkir yang memadai, tersedianya toilet, mushollah, pusat informasi, money changer, ATM, dan hotel juga telah teredia di wisata Pantai Pasir Putih. Namun dalam aspek indikator berupa facility exterior menurut responden masih kurang memadai. Dilihat dari konsep kantor, hotel, reseptionis, dan pusat informasi memiliki tata ruang dan fasilitas yang kurang mendukung. Untuk aspek indikator terakhir adalah other tangible, aspek ini adalah pelengkap dari facility exteror dan facility interior. Dilihat dari seragam karyawan, situs web, serta media sosial yang telah dimiliki oleh wisata Pantai Pasir Putih sudah sangat memadai. Hasil yang diperoleh dari penyebaran kuisioner, memperoleh hasil bahwa responden banyak yang memberikan jawaban mereka akan memilih tempat wisata yang memiliki lahan parkir yang mudah dijangkau, tersedianya tempat ibadah, toilet dan faktor pendukung dari usaha jasa itu sendiri. Hal ini menyebabkan perusahaan jasa berusaha semaksimal mungkin untuk melengkapi aspek physical pvidence ditinjau dari karakter jasa yang berbeda dengan sebuah produk.

\section{KESIMPULAN}

Berdasarkan analisis data dan pembahasan hasilnya terbukti adanya pengaruh event pariwisata terhadap keputusan berkunjung. Hasil yang kedua adalah terdapat pengaruh positif antara physical evidence terhadap keputusan berkunjung. Variabel event pariwisata dan physical evidence ini dapat digunakan sebagai pembanding dalam penelitian selanjutnya dengan variabel yang sama. Batasannya adalah periode yang dilakukan bersamaan dengan pandemi covid-19 dan ada kebijakan pemerintah untuk menutup tempat wisata demi mengurangi penyebaran virus tersebut, sehingga jumlah responden hanya 50. Disarankan untuk memperluas cangkupan responden, membandingkan beberapa tempat wisata yang berbeda, serta meknambah variabel lain seperti harga dari bauran pemasaran. Penambahan variabel harga diharapkan dapat mengetahui kualitas dan spesifikasi event pariwisata yang seperti apa yang diingankan oleh masyarakat ditinjau dengan kekuatan masyarakat untuk membeli tiket masuk event pariwisata tersebut. Hasil penelitian ini dapat digunakan sebagai bahan evaluasi promosi melalui event pariwisata dan evaluasi aspek dari physical evidence bagi pemerintah dan pengelola daerah wisata Pantai Pasir Putih Kabupaten Situbondo

\section{DAFTAR PUSTAKA}

Ananda, R. P., Ahman, E., \& Ridwanudin, O. (2016). Pengaruh Physical Evidence Objek Wisata Pemandian Air Panas Ciwalini terhadap Keputusan Berkunjung Wisatawan (Survei pada Wisatawan Nusantara Pemandian Air Panas Ciwalini-Ciwidey Kabupaten Bandung). THE Journal: Tourism and Hospitality Essentials Journal, 3(1), 461. https://doi.org/10.17509/thej.v3i1.1966 
Any, N. (2013). Manajemen Event (2nd ed.). Bandung: CV. Alfabeta.

Çelik, S., \& Çetinkaya, M. Y. (2013). Festivals in Event Tourism : the Case of International Izmir Art Festival. International Journal of Contemporary Economics and Administrative Sciences, 3(1), $1-21$.

CNN Indonesia. (2018). Situbondo Berbenah untuk Sambut Tahun Kunjungan Wisata. (https://www.cnnindonesia.com/gaya-hidup/20180301123008-269-279669/situbondoberbenah-untuk-sambut-tahun-kunjungan-wisata, diakses pada 20 Mei 2019)

Daniel, S., Achmad, F., \& Ari, I. (2018). Pengaruh Event Pariwisata Terhadap Keputusan Berkunjung ( Survei pada Wisatawan Domestik yang Berkunjung ke Event Pariwisata di Kabupaten Banyuwangi ). Jurnal Administrasi Bisnis, Vol 61(3), 144-153.

Erisha, M., \& Razati, G. (2017). Pengaruh Kinerja People dan Physical Evidence terhadap Keputusan Berkunjung (Survei Terhadap Tamu Hotel Kampung Sumber Alam Garut). Journal of Business Management Education (JBME), 1(2), 17-24. https://doi.org/10.17509/jbme.v1i2.5878

Fitriani, M., \& Andari, R. (2016). Meningkatkan Keputusan Berkunjung melalui Spesial Event di Museum Konperensi Asia Afrika (Survei pada Pengunjung Special Event Perjalanan 50 Tahun Gerakan Non Blok Museum Konperensi Asia Afrika). THE Journal : Tourism and Hospitality Essentials Journal, 3(2), 619. https://doi.org/10.17509/thej.v3i2.1974

Getz, D. (2008). Event Tourism: Definition, Evolution, and Research. Tourism Management, 29(3), 403-428. https://doi.org/10.1016/j.tourman.2007.07.017

Ghozali, I. (2011). Aplikasi Analisis Multivariate dengan Program IBM SPSS 23 (Hendryadi (ed.); Lima). Yogyakarta. Badan Penerbit Universitas Dipenogoro.

Hartiningsih, S., \& Rokhmah, B. E. (2017). Bauran Pemasaran (4P+ Physical Evidence) dan Pengaruhnya terhadap Keputusan Konsumen dalam Menggunakan Jasa Laboratorium Klinik Prodia Surakarta. Media Ekonomi dan Manajemen. 32 (1): 28-34. https://doi.org/10.24856/mem.v32i1.462

Henry, A. (1992). Consumer Behavior and Marketing Action (4th ed). Boston: PWS-Kent.

Higgins, F. (2018). Event Tourism and Event Imposition: A Critical Case Study from Kangaroo Island, $\begin{array}{lllll}\text { South } \quad \text { Australia. } & \text { Tourism }\end{array}$ https://doi.org/10.1016/J.TOURMAN.2017.08.002

J. Paul, P. \&, \& C Olson, J. (2013). Perilaku Konsumen dan Strategi Pemasaran (D. Diah Tantri (ed.); 9th ed.). Jakarta: Salemba Empat.

Kahuno, M. N. (2017). The Case Of Lamu Cultural Festival In Kenya. University of Pretoria, 04(201703-31), 26.

Lovelock, Christopher, \& Wirtz, L. (2011). Service Marketing (7th ed.). New Jersey: Pearson Hall.

Malhotra, N. (2009). Riset Pemasaran:Pendekatan Terapan.Jilid I.Edisi Keempat. (Empat). Jakarta: Jakarta Indeks.

Pakarti, S., Andriani, K., \& Mawardi, Kholid m. (2017). Pengaruh City Branding dan Event Pariwisata terhadap Keputusan Berkunjung serta Dampaknya pada Minat Berkunjung Kembali ke Kabupaten Banyuwangi . Jurnal Administrasi Bisnis, 47(1), 1-8. 
Fahmiroellah Fariz Ismail \& Sri Setyo Iriani. Pengaruh Event Pariwisata dan Physical evidence terhadap Keputusan Berkunjung

Ratih, H. (2008). Bauran Pemasaran dan Loyalitas Konsumen (1st ed.). Bandung: Alfabeta.

Sabrilia, T., Andari, R., \& Abdullah, T. (2016). Pengaruh Physical Evidence terhadap Keputusan Pembelian Konsumen di Happy Cow Palasar Bandung. Gastronomy Tourism, 2 No 2(2), 180188. https://ejournal.upi.edu/index.php/gastur/article/view/3610/2569

Sahabatnesia.com. (2018). 17 Pengaruh Letak Geografis Indonesia Beserta Pengertiannya. (https://sahabatnesia.com/pengaruh-letak-geografis-indonesia/, diakses pada 22 Mei 2019)

Sarsi, H., \& Betty, E. R. (2017). Bauran Pemasaran (4P+Physical Evidence) dan Pengaruhnya terhadap Keputusan Konsumen dalam Menggunakan Jasa Laboratorium Klinik Prodia Surakarta. Media Ekonomi Dan Manajemen, 14. http://jurnal.untagsmg.ac.id/index.php/fe/article/viewFile/462/508

Soundrenaline.id. (2019). Jadwal Soundrenaline. (Soundrenaline.Id/Faq, 23. soundrenaline.id/faq, diakses pada 29 Juli 2021)

Sumarwan, U. (2015). Pemasaran Strategik: Perspektif Perilaku Konsumen dan Marketing Plan (1st ed.). Bogor: IPB Press.

Visitingjogja.com. (2016). Informasi Agenda Event Wisata di Yogyakarta. Visitingjogja.Com, 46. (https://visitingjogja.com/event-agenda-pariwisata-jogja/page/46/, diakses pada 29 Juli 2021)

Yazid. (2008). Pemasaran Jasa dan Konsep Implementasi (VIII). Yogyakarta: Ekonesia. 